\title{
ANALYSIS OF THE GEOECOLOGICAL SITUATION IN KALUSH: CURRENT SITUATION AND WAYS OF SOLVING THE PROBLEM
}

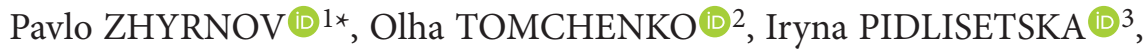 \\ Olena MYKOLAENKO ${ }^{3} 3$ \\ ${ }^{1}$ State Enterprise "Scientific Research and Design Urban Development Institute", Kyiv, Ukraine \\ ${ }^{2}$ Scientific Centre for Aerospace Research of the Earth, Institute of Geological Sciences \\ of the National Academy of Sciences of Ukraine, Kyiv, Ukraine \\ ${ }^{3}$ Faculty of Geography, Taras Shevchenko National University of Kyiv, Kyiv, Ukraine
}

Received 29 July 2020; accepted 29 October 2021

\begin{abstract}
Careless economic activity of chemical and mining enterprises of the Kalush-Holyn potassium salts deposit has caused ecological disbalance in a subsurface rock layers. This caused a technogenic disaster in Kalush such as the intensification of dangerous geological processes: flooding and waterlogging of lands, intensification of karst and suffusion processes, deterioration of groundwater and surface water. The study results of the geoecological situation in Kalush using research reports' materials of the specialized state enterprises and relevant thematic maps; and interpretation of remote sensing data are higlighted in the article. Comprehensive map of the geoecological situation of Kalush was developed in order to visualize the processes associated with the deformation of the earth's surface in the area of Kalush and other negative phenomena that must be taken into account when planning the development of the city.
\end{abstract}

Keywords: subsidence of the earth's surface, deposit of potassium salts, geoecological situation, exogenous processes, space images.

\section{Introduction}

The ecological balance in the Kalush-Holyn deposit's rocks was disturbed because of incorrect decisions made at the time regarding the development of the potassium salts deposit, location and operation of tailings dumps, storage tanks and the liquidation method of mine cavities that formed through negligent economic activities of chemical and mining enterprises in Ivano-Frankivsk region. This caused numerous landslides over the minery fields area, the buildings and communications destruction, aquifers salinization in the city (Holovchak, 2010).

A meeting of the National Security and Defense Council of Ukraine was devoted to the Kalush ecological situation in February 2010. As a result, Presidential Decree No145 / 2010 "On declaring the territories of the city of Kalush and the villages of Kropyvnyk and Sivka-Kaluska of the Kalush district of Ivano-Frankivsk region a zone of ecological emergency" (Figure 1) and the law to confirm it were adopted (Office of the President of Ukraine, 2010). The decree and the law stipulate that the Cabinet of Ministers of Ukraine must urgently ensure the people voluntary resettlement from the earth's surface subsidence territory, the formation of collapse sinkhole, karsts, landslides, with mandatory provision of their living space for temporary and further permanent residence; precautionary measures implementation to prevent drinking water sources contamination; technical measures implementation for strengthening, waterproofing, reducing the brine growth dynamics in the Dombrovsky quarry of potassium ores. In addition, the government intended to strengthen the tailings dam No 2 of the Kalush-Holyn potassium salt's deposit; research of the toxic waste landfill, development and implementation of a set measures to localize the pollution by toxic waste source and to eliminate such pollution consequences.

The Parliament of the Republic of Moldova in September 2012 stated that the situation at the Dombrovsky quarry in Kalush is catastrophic. There has formed a sedimentation tank saturated with brines, debris and hazardous substances. This situation could cause an environmental disaster by breaking through an unfortified dam to the Dniester River, which is a cross-border between Ukraine and Moldova. Consequently, the Dniester will receive about 2 million $\mathrm{m}^{3}$ of a dangerous brines mixture,

${ }^{*}$ Corresponding author. E-mail: zhirnovpavel2015@gmail.com

Copyright $\odot 2021$ The Author(s). Published by Vilnius Gediminas Technical University

This is an Open Access article distributed under the terms of the Creative Commons Attribution License (http://creativecommons.org/licenses/by/4.0/), which permits unrestricted use, distribution, and reproduction in any medium, provided the original author and source are credited. 
hazardous substances and salt-containing overburden, so Moldova (especially Chisinau) and part of the Odessa region may be left without drinking water.

These problems served as a basis for scientific research of the current geoecological situation in Kalush and the practical development of engineering solutions for the disturbed areas of the city. The scientific article's topic is related to the development of the project "Master Plan of Kalush" SE "Research and Design Institute of Urban Planning" according to the agreement No 2017-107 from 21.09.2017 between the company and the Executive Committee of Kalush City Council (Kolodova et al., 2020).

The article's aim is to study the geoecological situation in Kalush using research reports' materials of the specialized state enterprises and relevant thematic maps; and interpretation of remote sensing data to visualize the

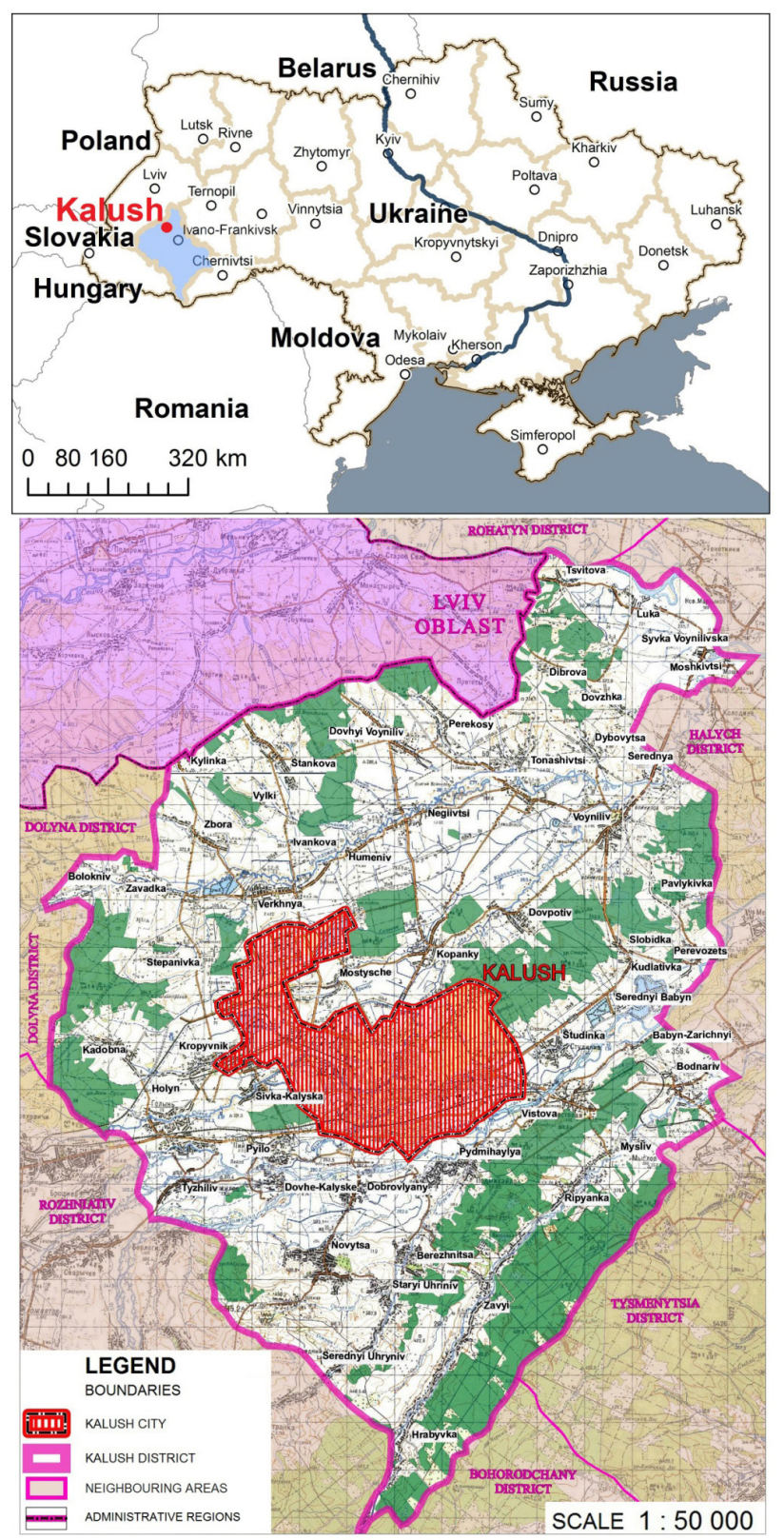

Figure 1. Study area - Kalush city and its suburbs processes associated with the earth's surface deformation near Kalush and other negative phenomena, that must be taken into account when planning the development of the city. Selected dangerous and threatening zones of landslide, which arise as a result of salt deposits' underground development, as well as the spread of groundwater pollution's areas within the influence of mining and technological facilities.

It should be noted that the situation in Kalush was formed over many years, it was studied by various institutions, government and scientific organizations such as: Ivano-Frankivsk National Technical University of Oil and Gas, Institute for Nature Management Problems and Ecology of National Academy of Sciences of Ukraine, Institute of Geophysics of the National Academy of Sciences of Ukraine by S.I. Sibbotin name, Prykarpattia SE Special Geological Exploration, SE "Research Institute of Galurgy", etc. which is covered in publications (Shurovsky et al., 2012; Krizhanivsky et al., 2008; Bagriy, 2009, 2016; Bagriy \& Kuzmenko, 2011). So, the problems, their causes and ways to solve them have been known for a long time, but the situation remains catastrophic to this day.

\section{Study area}

The earth's surface subsidence over the mine workings is one of the most significant technogenic manifestations of the mining operations' impact on the geological environment. The elimination of groundwater pollution sources and the reclamation of disturbed lands on the mining and technological facilities' territory of Kalush's potash and magnesium former production remain relevant today. Negative changes in the geological environment largely depend on the mines' development and elimination methods, and on the geological-hydrogeological and structural-tectonic natural conditions, which in each case have their own specifics. Potassium salt extraction in the Kalush-Holyn deposit was carried out in two ways: open (Dombrovsky quarry) and mine (Kalush and Novo-Golyn mines). The effects of open pit potash extraction, which has been field-tested in this area for the first time in the world, are currently catastrophic for the environment.

The development of the earth's surface subsidence is associated with a decrease in the engineering and geological rocks' stability, the decomposition of the arrays overlying the underground workings, the stress' redistribution around the produced space. The mineral deposits' extraction causes considerable size voids' formation in the earth's bowels. The rocks that lie in the mine's overlying workings under the action of gravity and pressure come into motion, causing the development of the displacement process of the entire thickness, including the earth's surface, in which there is a violation of their integrity with the formation of new cracks' areas. At the same time, dangerous geological processes arise or become more active (lands' flooding and waterlogging, intensification of karst and suffusion processes, etc., the quality of groundwater and surface water deteriorates). These processes negatively 
affect the normal buildings' operation, structures and lines of utilities, which are located in the area affected by mining, and also lead to changes in the natural regime of groundwater, flooding of the earth's surface, waterlogging, formation of dips that pose a danger to the population and ground objects. The scale of such changes in the ecological environment depends on many factors, both natural circumstances and the validity of certain engineering decisions. (Chepurnyi et al., 2020).

Potassium salts were mined at three mines and the only open-pit Dombrowski quarry in the world, and raw materials were processed at a potash plant and later at a chemical and metallurgical plant. The Kalush mine has been in operation for more than a hundred years. Currently, the mine has been liquidated by filling the spent cavities with salt brines. Part of the Kalush city sections are located above the produced space of the mine "Kalush" and in the zone of its influence. This causes dangerous engineering and geological processes: the earth's surface subsidence, the formation of dips, karsts, landslides, pollution of grants, surface and groundwater.

The Novo-Golyn mine was operated from 1966 to 1995. During its operation, 12 million $\mathrm{m}^{3}$ of underground cavities were formed. The Golyn mine was operated from 1930 to 1972 , the total cavities' volume was 1.7 million $\mathrm{m}^{3}$. The reserves of the Golyn mine were depleted, and it was decommissioned in 1995. It is eliminated by flooding with brine now. The construction of the Pilo mine was started to support potash mining facilities in 1979. In the late 80's construction stopped.

The Dombrovsky potash quarry has been in operation since 1967, during the entire period of its operation 35.4 million $\mathrm{m}^{3}$ of rock was extracted. Operation ceased in 2007. The quarry is currently being flooded naturally. The southern and northern parts are filled with brines in the amount of more than 13 million $\mathrm{m}^{3}$.

Mining of kainite and sylvinite ores was carried out in separate mine fields: northern sylvinite, northern kainite, central and Khotyn. Much of the Kalush city territory was in the workings influence zone of the mine "Kalush". Ore deposits have a complex polymineral composition, with a significant content of sulfate minerals and insoluble residue. During the operation of potash mines and quarries, as well as as a result of subsequent processing of extracted minerals, a large amount of liquid and solid waste was formed, which was stored on the earth's surface.

Exogenous processes on the territory of Kalush are represented by flooding, salinization, aggressiveness of surface and groundwater, waterlogging, gravitational processes, deformation of rocks over underground mine workings, manifestations of karst and suffusion. The development dynamics of exogenous geological processes can be traced by comparison multi-temporal space images.

\section{Data and methodology}

Scientific articles' processing which were dedicated to using methods of precision gravity gradiometry and electrical exploration for researching and forecasting dynamic's karst developing and earth surface's failures on the territory of the spent Kalush-Golynsky deposit of potassium salts were produced by writing a current article (Shurovsky et al., 2012; Yosipenko, 2012). Article's results devoted to method interferometry had been taken into account for the earth surface deformations' analysis, landslides' value clarifying at Khotin ore field (Pakshyn et al., 2019). Environmental status of Kalush mining area's problem objects by electromagnetic methods for identification, studying and timely prevention of such processes as karst, suffusion, landslides were processed in some articles (Deshchytsya et al., 2016). Articles about natural and technogenic karst mapping, zones' identification of rocks' erosion in the mine workings' limits and failures, rocks' deformations on the earth surface were explored (Bagriy, 2009; Bagriy \& Kuzmenko, 2011). Work analysis aimed at failures and subsidences' identification in the ore fields' limits and aquifer's pollution by mine enterprises' wastes with geophysical method using of the natural pulsed Earth's electromagnetic field was conducted (Bagriy, 2016). The information about waste storage sites, risks' assessment associated with their operation and TMFs' monitoring No 1, 2, 3 for the adequate danger degree's assessment and prevention of chemicals' leakage stored at them is displayed in some scientific works (Malyk et al., 2013). Analysis of technogenical and natural factors that affected the salt karst development in Kalush was based on some articles (Pavliuk, 2016; Chepurnyi et al., 2020) Authors' previous scientific researches, which describe engineering geological zoning's methodology and engineering construction assessment of city with difficult geodynamic and geoecological situation taken into account in the current article (Mykolaenko et al., 2019; Zhyrnov et al., 2019; Trofimov \& Krasilova, 2008). Corresponding scientific report was analysed for the engineering geological restrictions' allocation of Kalush (Sadoviy \& Tsimbalista, 2017). The problem of flooded technogenical territories and rivers' salinization of Kalush was analysed in a separate article (Gajdin et al., 2014). Articles focused on geologic environment's ecological status in the zone of influence of Kalush potash mining industry and implement decisions in the sphere of environmental situation's improving have been analysed (Krizhanivsky et al., 2008; Rudko \& Petryshyn, 2015; Holovchak, 2010).

The initial data for the study and mapping of the territory current state were: reports of the State Enterprise "Ukrgeophysics" (Yosipenko, 2012), SE "Halurgy Research Institute" (Sadoviy \& Tsimbalista, 2017), geological map of Kalush-Holyn potassium salt's deposit (scale 1: 10 000) and its geological and surveying section, topographic and geodetic survey of the territory of Kalush (scale 1: 10 000), reciprocally incorporated plan of Kalush mine from industry association "Chlorinevinyl" (scale 1: 10 000), the layout of industrial facilities of LTD "Karpatnaftochim" and PE "Lukor" in Kalush (scale 1:10 000) and multitemporal space images of high spatial resolution. 
These source data were graphically interpreted as a result of analytical work as follows:

- digitized topographic and geodetic survey on the Kalush territory;

- natural and technogenic geomorphological areas were allocated, with the subsequent detailing of natural areas on various degree slopes' steepness;

- digitized environmental and engineering-geological planning constraints;

- the groundwater level was indicated, which is the first from the surface for each geomorphological area;

- areas with endogenous and exogenous geological processes were allocated using remote sensing data.

Processing and visualization of the obtained data was performed using modern geoinformation technologies, namely the ArcGIS software package in particular the modules Spatial Analyst, 3D Analyst and Geostatistical Analyst for creating, analyzing and obtaining information from surfaces.

Technogenic landforms were identified based on reports of the State Enterprise "Halurgy Research Institute" (Sadoviy \& Tsimbalista, 2017): dumps of potassioum ores "Galda" processing waste, external dumps of overburden No 1 and No 2 Dombrovsky quarry that accumulating tanks No 1 and No 2 of the Dombrovsky quarry, tailings No 1 and No 2 of the SE potassium factory of OJSC "Oriana" and its sludge accumulator, slag and ash dumps of Kalush CHP, sylvinite and kainite shale ore fields and abandoned karst raw materials.

Planning constraints of engineering and ecologicalgeological character, and also geodynamic processes were analyzed in addition for allocation of sites of various degree of suitability. These included the boundaries of mining branches location near mining enterprises and zero contours of subsidence troughs above underground workings. Areal of groundwater's salinization and isolated incidents of burial packing with hexachlorobenzene related to ecological geological planning restrictions. These restrictions signal about primary urgent reclamation and protective measures on whose realization the ecological balance of geological environment of city and the health of him inhabitants in future depends.

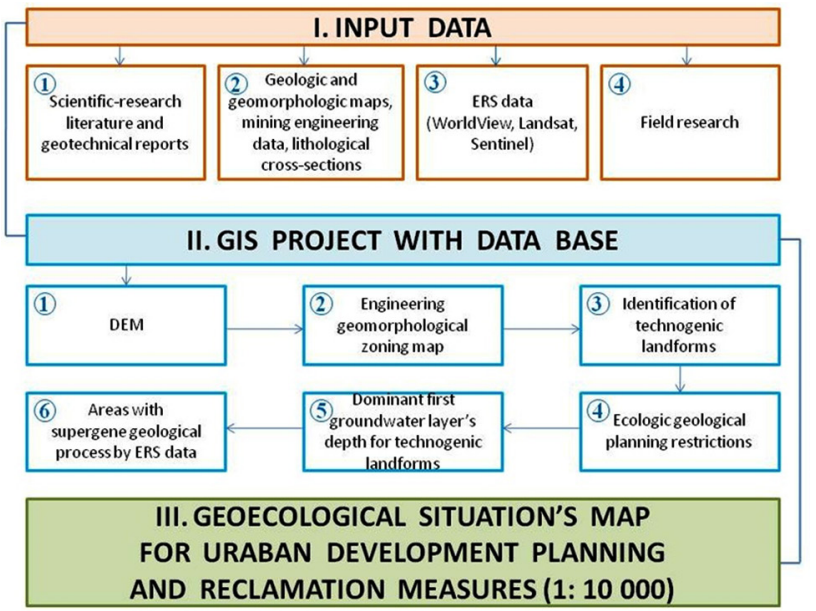

Figure 2. Data and methodology of current research
Remote images of the Earth are an important source of data in the study of geodynamics and modern exogenous processes monitoring. The integrated use of traditional geological and geophysical methods of studying the geoecological situation and remote sensing methods allowed to optimize the network of ground research and extrapolate the data obtained as a result of their implementation into a comprehensive thematic map of the Kalush geoecological situation (Figure 2).

\section{The results of the research}

Such technogenic objects were allocated on the Kalush area among violated territories that destructive impact on geological environmental status: TMF No 1 and No 2, sludge tank of OAO "Oriana" potash plant, Kalush mine, which included Dombrowski quarry's refuse heaps and bowl with mineralized liquid phase, North sylvinite ore field, North kainite ore field, Central kainite ore field and Khotin sylvinite ore field, polygon of hexachlorobenzene's toxic waste, abandoned quarry of clay raw materials.

TMF No 1 worked out intermittently 1967-1987 years and completed to the project level. It has a surface square of 54.3 ha and a volume of 15 million $\mathrm{m}^{3}$. TMF consisted of 2 sumps separated by earthen dam at the initial stage of operation. One of them was intended for halite storage (halite and the bulk's sludge after flotation), another one was intended for mud sludge storage after the main (sulphate) production cycle. Liquid waste from treatment facilities of CJSC "Lukor" contained on the TMF's surface. To date there is no opportunity to support it safety in connection with production activities' termination. Active karst processes' development happens on his surface and in the deep of technogenic saline sediment. The constant brine outwash is continuing through the dam all over its perimeter and through the TMF's bottom. Saline components, elements and other chemical compounds are dispersed from this object into the environment during the last 50 years, creating a technogenic stress on the ecosystem and in particular on the area's hydrosphere. Solutions' mineralization dispersing in hundreds of locations from TMF No 1 is changing from 10 to $420 \mathrm{~g} / \mathrm{l}$ over an initial probs. Water mineralization was over $150 \mathrm{~g} / \mathrm{l}$ in the observing well, which situated in the south from TMF. The volume of dispersing into environment salts is difficult to quantify, it can be close to millions of tons in accordance with some assessments (Malyk et al., 2013).

TMF's No 2 construction began on the 1984 year. It has a square of 48 ha and a general volume of 9.7 millions $\mathrm{m}^{3}$, which is filled with waste: solid phase's quantity at the closure moment was 8 million $\mathrm{m}^{3}$ and a liquid phase's quantity was 1,7 millions $\mathrm{m}^{3}$. Anti-filter screen from stabilized polyethylene film with loam layer was laid on the TMF's bottom and dam's slopes with the aim of brines' filtration avoidance. Using of such film was intended while TMF's building, but this measure has not been implemented. Active brines' penetration through the dam has been observed in recent times what was the cause of its 
gradual destruction and technogenic environmental risks' increasing. Ensure sustainability of salts' storage and brine solutions' avoidance from the TMF to the environment couldn't be without measures' execution designed to support the construction's functioning in the normal operations. The constant brines' outwash outside the facility and their spreading in the environment are continuing as well as at the TMF No 1. Brine's mineralization in the subsurface layer depends on rainfall quantity and varies from 60 to $100 \mathrm{~g} / \mathrm{l}$. Brines' concentration is sharply increasing with depth and exceed $250 \mathrm{~g} / \mathrm{l}$ at 3 levels extending from the surface and exceed $400 \mathrm{~g} / \mathrm{l}$ at the lowest bottom's sections (in the interval 8-11 m). Samples dated 2014 year from the source in the TMF's No 2 eastern corner indicated the mineralization at the $405 \mathrm{~g} / \mathrm{l}$ level. Brines' outwash, surrounding territories' and streams' salinization, potential technogenic commodity's losing, construction's damage due to natural and technogenic erosion processes are the basic facility's problems and threats (Malyk et al., 2013).

Sludge tank of OAO "Oriana" potash plant is overcrowded for a long time. Volume's growth of located here mineralized waters is called by the rainfall's direct ingestion on the sludge tank's surface and by the brines' run-off from the TMF's No 1 northern side. They are channeled through mud-hole at the several locations of sludge tanks' locations and entered to the surrounding bowl of TMF's No 3 unfinished first phase. There has been a quantity's decrease of liquid phase's mineralization during researches. While in previous years salt concentration reached $170 \mathrm{~g} / \mathrm{l}$ or even $200 \mathrm{~g} / \mathrm{l}$ in the solution, then up-to-date information those indexes are approximately $90 \mathrm{~g} / \mathrm{l}$.
North sylvinite ore field was worked out during 1946-1962 years, the formed voids' volume is 1880 thousands $\mathrm{m}^{3}$ at the depth of $160-440 \mathrm{~m}$ with a safety pillars' height of 3-28 m, width of 11-12 m and a safety pillars' width of 5-8 m. Salt extraction's coefficient amounted to $64 \%$. Worked out safety pillars' volume was at 1850 thousand $\mathrm{m}^{3}$. Worked out safety pillars filled with solid barren rock upper than VI aquifer, but lower lay was filled with suspension of chemical factory's waste (water filling). Last instrumental measurements of earth's surface subsidence were performed by unsinkable reference points at 1989 year. Maximum subsidence rates were at 3-5 mm per year. Subsidence is continuing with maximum rate at $10-12 \mathrm{~mm}$ per year in the center of landslide's trough. Subsidence is projected with maximum depth at $5.1 \mathrm{~m}$ in the trough's center at North sylvinite ore field. Beginning stages and active phase above ore field have taken place during which the fastest rate was in 1961 year and it was $450 \mathrm{~mm}$ per year. Landslide's damping stage is currently taking place at this field. Safety pillars have already been destroyed and the rock is thickening. There are no any residential buildings and industrial facilities at this field.

North kainite ore field is a stratiform deposit with descent's angle of $25-30^{\circ}$ and capacity from 3 to $35 \mathrm{~m}$. Layer was worked out during 1956-1975 year at a depth of 100 to $220 \mathrm{~m}$ and widths' pillar was of $4.8-10.0 \mathrm{~m}$. In general 1326 thousand tons $\mathrm{m}^{3}$ were extracted. The volume of $6120 \mathrm{~m}^{3}$ chemical factory's waste was pumped by pipeline running on III aquifer into cameras No 7-12 during 1965-1967 years. The field was divided into 3 sites with different mining parameters by barrier pillars of $40-42 \mathrm{~m}$

Table 1. Sinkholes' characteristic which formed at the North kainite ore field

\begin{tabular}{|c|c|c|c|c|c|c|}
\hline $\begin{array}{l}\text { Sinkhole } \\
\text { number }\end{array}$ & Date formation & Sinkhole size, $\mathrm{m}$ & $\begin{array}{l}\text { Sinkhole } \\
\text { volume, } \\
\mathrm{m}^{3}\end{array}$ & Sinkhole location & $\begin{array}{l}\text { Distance from } \\
\text { the surface to the } \\
\text { sinkhole cover }\end{array}$ & Sinkhole condition \\
\hline 4 & 15.03 .1984 & $5.0 \times 5.0 \times 0.5$ & 12.5 & $\begin{array}{c}\text { Alkaline camera } \\
\text { No } 10\end{array}$ & $63(65)$ & $\begin{array}{l}\text { Levelled with plaster } \\
\text { argillaceous cap }\end{array}$ \\
\hline $4 a$ & 10.09 .1985 & $1.5 \times 1.0 \times 1.0$ & 1.5 & $-1 /-$ & $-/ /-$ & $-/ /-$ \\
\hline $4 \mathrm{~b}$ & 15.09 .1985 & $4.2 \times 2.0 \times 1.5$ & 12.6 & $-/ /-$ & $-/ /-$ & $-/ /-$ \\
\hline $4 \mathrm{c}$ & 18.12 .1985 & $2.0 \times 1.5 \times 1.0$ & 3.0 & $-1 /-$ & $-1 /-$ & $-1 /-$ \\
\hline 5 & 27.06 .1986 & $15.0 \times 15.0 \times 6.5$ & 1462 & Camera No 33c & $90(95)$ & $-/ /-$ \\
\hline 7 & 07.07.1987 & $18.8 \times 17.5 \times 8.0$ & 2632 & Camera No 7 & $92(122)$ & $-/ /-$ \\
\hline 8 & 29.06 .1990 & $14.0 \times 14.0 \times 7.0$ & 1372 & Camera No 33c & $112(125)$ & $-/ /-$ \\
\hline 10 & 19.07.1995 & $20.0 \times 30.0 \times 17.0$ & 10250 & Cameras No 4,5,6,7 & $90(117)$ & $-1 /-$ \\
\hline $10 \mathrm{a}$ & 24.07 .1996 & $14.0 \times 16.0 \times 6.0$ & 1344 & $-1 /-$ & $-/ /-$ & $-/ /-$ \\
\hline $10 \mathrm{~b}$ & 12.02 .1997 & $29.0 \times 31.0 \times 25.0$ & 22475 & $-1 /-$ & $-1 /-$ & $-1 /-$ \\
\hline 12 & 15.12 .2001 & $25.7 \times 21.5 \times 15.0$ & 8289 & Camera No 3 & $120(140)$ & $-/ /-$ \\
\hline 12 & 15.07 .2003 & $9.0 \times 12.0$ & 3024 & Cameras No 3,2 & $110(131)$ & $-1 /-$ \\
\hline 14 & 22.07 .2008 & & 11722 & Cameras No 36,35 & $118(145)$ & Backfill not finished yet \\
\hline 14 & 12.2009 & $11.0 \times 19.0 \times 28.0$ & & $-/ /-$ & & $-/ /-$ \\
\hline 14 & 01.01 .2016 & Diameter 40 & & $-1 /-$ & & \\
\hline 15 & 01.04 .2009 & $15.0 \times 18.0 \times 3.0$ & 810 & Camera No 33b & $112(140)$ & No backfill \\
\hline $14 \mathrm{a}$ & 16.11 .2015 & $\begin{array}{l}\text { Diameter } 26 \mathrm{~m} . \\
\text { depth } 19 \mathrm{~m}\end{array}$ & 10275 & $\begin{array}{l}\text { Cameras } \\
\text { No } 34,33\end{array}$ & $120(143)$ & No backfill \\
\hline
\end{tabular}


in width during layers' operating. Accordingly earth's subsidence was happening with different rates and gradually escalating, but their indexes were moderate. In 1986 year they were: at the north site was $20-25 \mathrm{~mm}$ per year, at the center site was 3-5 $\mathrm{mm}$ per year, at the south site was 8-12 mm per year. Situation had become more complex after sinkhole's No 4 formation in the south field's part in 1984 year through the landslide activated after safety pillars' deformation and also karst and suffusion, which have intensified after rock mass shift. Karst processes are actively developing despite the earth surface landslide's stabilization above the ore field as a result of which karst sinkholes surfacing (Deshchytsya et al., 2016). Fourteen sinkholes have been formed above this field at the central site (see Table 1).

Earth's subsidences at the North kainite ore field which have been located due to high resolution space images' analysis visible in the Figure 3. There is a tendency of size's increasing of sinkholes. Dynamic's tracking of sinkhole's size which was formed in October of 2008 year and sizes of which were $11 \times 19 \times 28 \mathrm{~m}$ indicate that it increased in size, became round with $40 \mathrm{~m}$ diameter as at December of 2015 year. The general length of created sinkhole was 67 meters since it joined with sinkhole No 14a (Mykolaenko et al., 2019). The sinkhole is drained and preserved at present time.

Central kainite ore field. 11 cameras, 9 lens of potassium salt in 1920-1945 years and 2 lens of potassium salt in 1963-1978 years were worked out at the Central kainite ore field until the end of the Kalush mine's exploitation. Worked out cameras in the old workings have

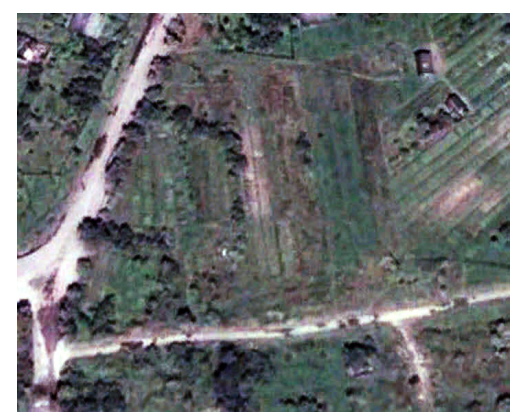

2005

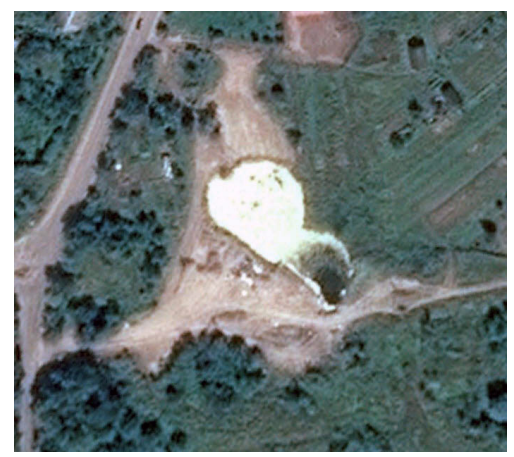

2017 tried to fill with solid materials: waste rock from new workings' excavation, slag from TPS, demolition waste and also with sludge, which was formed during ore processing. Filling of worked out cameras didn't reach the roof side on 1.5-2 m. The last two lenses (lower kainite and sylvinite-kainite) were worked out on the depth of $180-210 \mathrm{~m}$ with capacity from 4 to $33 \mathrm{~m}$. 105 residential buildings, industrial facilities, civilian development are in the area affected by Central field mine workings. Surface landslide's monitoring was started in 1947 year. Subsidence's rates gave changed from $20 \mathrm{~mm}$ per year to $40 \mathrm{~mm}$ per year at beginning of monitoring. Surface landslide above the old mine workings is at the damping stage with subsidence's' rates of 1-3 mm per year. Landslide process above the lower kainite and sylvinitekainite lens is at the beginning stages, the maximum subsidence's rates are in the limits of 3-5 mm per year. The final largest earth subsidence above "lower kainite" lens is forecast to $5.7 \mathrm{~m}$ and the same phenomenon above "upper kainite" to $1.5 \mathrm{~m}$. Above those lens European street runs along which 44 temporary reference points have been based on. Reference points' subsidence at some sites has been noted in recent years. The largest index of subsidence' rate was recorded in 2009 year and it was $84 \mathrm{~mm}$ per year. Subsidence trough with largest index of $500 \mathrm{~mm}$ has been formed over field. The last instrumental measuring of earth surface's condition near mine site was in September of 2008 year. There are 7 sinkholes have been formed and the subsidence trough had already begun to take share. The sinkholes' characteristic is set out in the Table 2 .

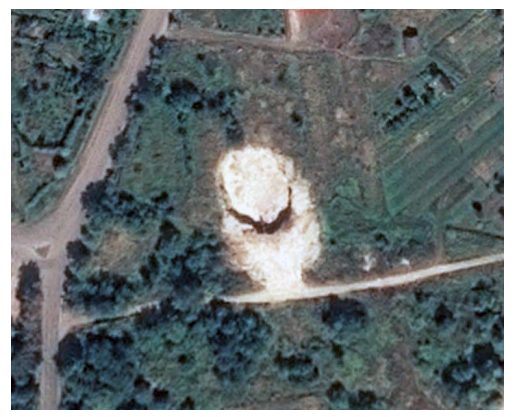

2013

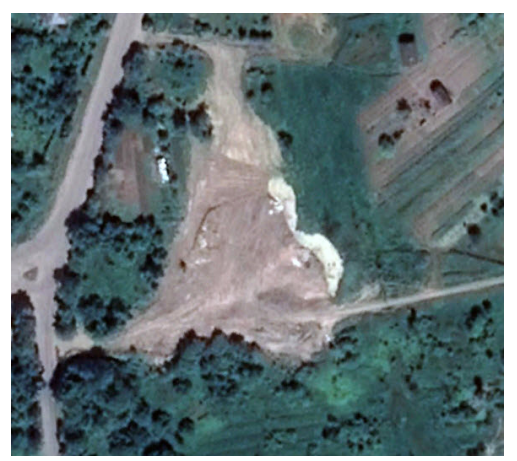

2018

Figure 3. Dynamic of sinkholes' formation 14 and $14 \mathrm{a}\left(49^{\circ} 2^{\prime} 35.64^{\prime \prime} 24^{\circ} 22^{\prime} 2.30^{\prime \prime}\right)$ at the North kainite field on space images 
Table 2. Sinkholes' characteristic have collected at the Central kainite ore field

\begin{tabular}{|c|c|c|c|l|c|}
\hline $\begin{array}{c}\text { Sinkhole } \\
\text { number }\end{array}$ & Date formation & Sinkhole size, $\mathrm{m}$ & $\begin{array}{c}\text { Sinkhole } \\
\text { volume, } \mathrm{m}^{3}\end{array}$ & \multicolumn{1}{|c|}{ Sinkhole location } & Sinkhole condition \\
\hline 1 & 10.03 .1975 & $3.0 \times 2.1 \times 4.0$ & 25 & Mine site at the central side & $\begin{array}{l}\text { Levelled with plaster } \\
\text { argillaceous rocks }\end{array}$ \\
\hline 2 & 10.12 .1975 & $5.0 \times 4.0 \times 3.0$ & 60 & $-/ /-$ & $-/ /-$ \\
\hline 3 & 01.03 .1980 & $6.5 \times 4.5 \times 4.0$ & 117 & Sivka riverbed & $-/ /-$ \\
\hline 6 & 24.01 .1986 & $13.5 \times 13.0 \times 8.4$ & 1474 & Reference point No 6 & $-/ /-$ \\
\hline 9 & 03.01 .1992 & $5.0 \times 4.3 \times 6.0$ & 139 & $\begin{array}{l}\text { Alkaline camera Rittenger at } \\
\text { the reference point No } 4\end{array}$ & $-/ /-$ \\
\hline 11 & 09.01 .1997 & $10.5 \times 8.5 \times 5.5$ & 491 & $\begin{array}{l}\text { Alkaline camera Rittenger at } \\
\text { the reference point No 4 }\end{array}$ & $-/ /-$ \\
\hline 13 & 25.06 .2007 & Diameter $10 \mathrm{~m}$ & 400 & $\begin{array}{l}\text { Alkaline camera Rittenger at } \\
\text { the reference point No 4 }\end{array}$ \\
\hline
\end{tabular}

Sinkhole has been formed in the site between former ventilation shafts in the limits of the Central kainite ore field in the summer of 2007 year. Pit of earth's surface was coupled with blow-out high mineralized solution was piled up and flowed to Sivka riverbed. Then the solution's streaming stopped, zone of the primary pit has expended and long tensile cracks were manifested by slope above the pit.

Khotin sylvinite ore field was worked out during 19311972 years at a depth of 140 to $270 \mathrm{~m}$, deposits' capacity in the field's center is $22 \mathrm{~m}$ and lens out to $2.5 \mathrm{~m}$ at the field's flanks. Cameras' width was 9.5-12.0 m, safety pillars' width was $5.5-8.0 \mathrm{~m}$, exploration coefficient of the rock was $63 \%$. The volume of working out voids was 947 thousand $\mathrm{m}^{3}$ and the volume of 125 thousand $\mathrm{m}^{3}$ was covered by rocks from mine. Rocks' covering was conducted on $75 \%$ in 11 and 13 cameras of VI aquifer and also the same at 34-48 cameras. Mining works were stopped in 1973 year and mining site was mothballed. Instrumental measuring of earth's subsidence above the Khotin sylvinite ore field started in 1957 year about 4 years early before their working out beginning and they carried out annually until 2009 year across specialized lines with soil reference points. 3 landslide's stages were recorded and now it is a damping stage, the subsidence' speed indexes reach maximum values of 18-22 mm per year (Pakshyn et al., 2019).

Subsidence trough with the depth of $3.5 \mathrm{~m}$ was formed, her center was filled with groundwater and the waterlogging square was at 2 ha. 109 one- and two-storey residential building, houses, facilities, construction, communication fall into the influence's zone of field's mine workings. Inhabitants of 26 residential houses were evicted due the waterlogging of subsidence trough's center. Voids' large volume remained in the limits of mine site during overburden rock strata's destruction and water's influx from aquifer and from Limnitsa riverbed. Sharp earth subsidence cannot be ruled out. Performed calculated of possible subsidence's forecast at the final stage above the Khotin field indicate that the maximum subsidence in the trough center will constitute about $7.4 \mathrm{~m}$.

Dombrowski quarry is a single potash quarry in the world, exploitable from 1967 year. 35.4 million $\mathrm{m}^{3}$ of mined rock were sourced during all exploitation period. Exploitation was stopped in 2007 year. The quarry is flooding by nature's way now. Southern and northern parts are filled with brines in the quantities greater than 13 million $\mathrm{m}^{3}$ nowadays. Mechanism for the establishment of salt brines in the Dombrowski quarry is a result of rainfall interaction with salt rocks; his volume belongs from rain quantity and watershed area. Water volume that entered the quarry was caught by drainage trench and partially left the quarry until 2008 year. Water pumping from drainage trench and from quarry has been suspended from 2008 year. Rainfall's watershed area has doubled due external refuse heaps No 1 and No 4 and interquarry strip surrounding to the inner side of the ring drainage trench in the 2008 year. Nowadays rainfall's watershed area is 360380 ha. Water inflow in the quarry only due to the rainfall taking into account the average annual rainfall quantity $(700 \mathrm{~mm})$ is $1.1-1.2$ million $\mathrm{m}^{3}$ per year. All water flow from gravel-and-shingle aquifer $\left(2\right.$ million $\left.\mathrm{m}^{3}\right)$ referred to the quarry after stopping of drainage water pumping in the external ponds. So, the general annual water flow in the quarry is 3.1-3.2 million $\mathrm{m}^{3}$ per year. Dombrowski quarry' waterlogging dynamic by brines and increasing of water table's square in 13 years from 24.5 ha to 90.7 ha (Figure 4, Table 3) were tracked due to ERS materials. The hazard from the quarry provoked by water level's increasing: precipitation in the West Ukraine's climatic zone exceeds the natural evaporation. An engineering solution of Dombrowski quarry's problems is the construction of anti-filtration curtain around quarry, refuse heaps No 1 and No 2, accumulation tanks No 1 and No 2 and gradual recycling of accumulated salt waste and brines.

The karst process has a trend to develop towards Sivka River by external side of drainage trench in the northwest part of the Dombrowski quarry. So, there is an opportunity for the Sivka River's breakthrough in the quarry. Specified processes lead to the sinkholes' formation at the quarry's boundary sites and rockfalls in the selected location near north side. Karst processes will develop further north will hurt or destroy garden plots and can reach Sivka riverbed, because the karst process is uninterrupted 


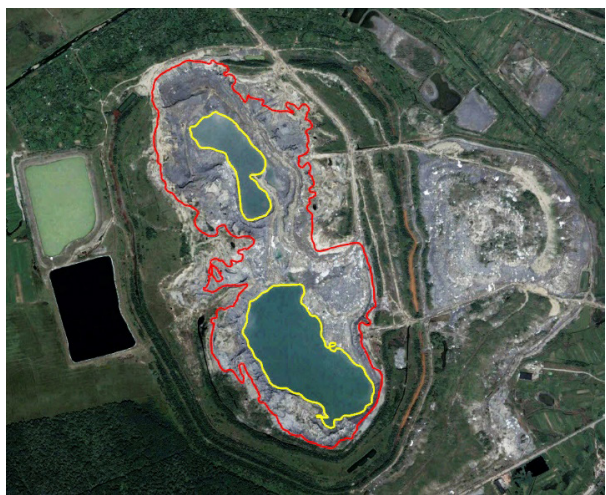

2005

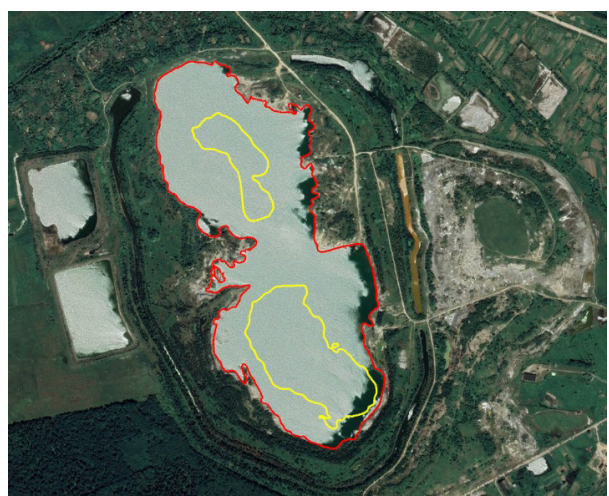

2018

Figure 4. Brines' waterlogging dynamic of Dombrowski quarry, look of space images. Quarry's filling selected by contours in such years: $2005+2018$

and salt seams are distributed further north. According to the forecast this river will never go down under the earth to the quarry (Pavliuk, 2016).

Aquifer's rocks, loams, top soil will subsidence during salt erosion. There is a risk of new Sivka riverbed's formation, which will connect present riverbed with the quarry. Earth exceeding between career and river in height above Sivka riverbed is $2.5-3 \mathrm{~m}$ maximum (Zhyrnov et al., 2019).

Table 3. Brines' waterlogging dynamic of Dombrowski quarry

\begin{tabular}{|l|c|c|c|c|c|}
\hline \multicolumn{1}{|c|}{ Years } & 2005 & 2011 & 2015 & 2017 & 2018 \\
\hline $\begin{array}{l}\text { Quarry's } \\
\text { square } \\
\text { filling by } \\
\text { water, ha }\end{array}$ & 24.6 & 45.3 & 70.5 & 85.9 & 90.7 \\
\hline
\end{tabular}

Waterlogging general square of all city is 1900.7 ha. Waterlogging causes are natural for floodplains and technogenic in limits of violated areas due to unsuccessful ore fields' conservation, Dombrowski quarry, groundwater hydrogeological regime's changes due to quarries' and mines' construction. Refuse heap "Halda", refuse heaps No 1 and No 4 of Dombrowski quarry, accumulation tanks No 1 and No 2 of Dombrowski quarry, North sylvinite and kainite fields, Central kainite and Khotin sylvinite ore fields are technogenic waterlogging territories in the Kalush city. Waterlogging square in limits of North sylvinite ore field is 56 ha nowadays. The forecast waterlogging square for the Central kainite field is 3.3 ha. The forecast waterlogging square for the North kainite field is 47 ha, for Khotin field is 40 ha. Trough's center of North kainite field is waterlogged nowadays; the waterlogging square of Khotin field is 2 ha.

Area of groundwater salinization is in limits of TMF No 1 No 2, sludge tank of OAO "Oriana" potash plant, external refuse heaps No 1 and No 4 of Dombrowski quarry, accumulative tanks No 1 and No 4 of Dombrowski quarry, refuse heap "Halda" and adjacent territories to those technogenic objects. Beside this process unloading of salinized groundwater aquifers is moving towards Limnitsa river's water intake posing a threat for water supply of Kalush inhabitants. In turn the Limnitsa riverbed is changing very dynamic that we can see on multi-temporal spaceimages (Figure 5). Moreover an aggressive influence of salinized groundwater on reinforced concrete structures requiring special protective measures implementation.

Polygon of hexachlorobenzene's toxic waste. Carbon tetrachloride and perchloroethylene proceeding was founded in 70's years of 20 century in Kalush in the course of which

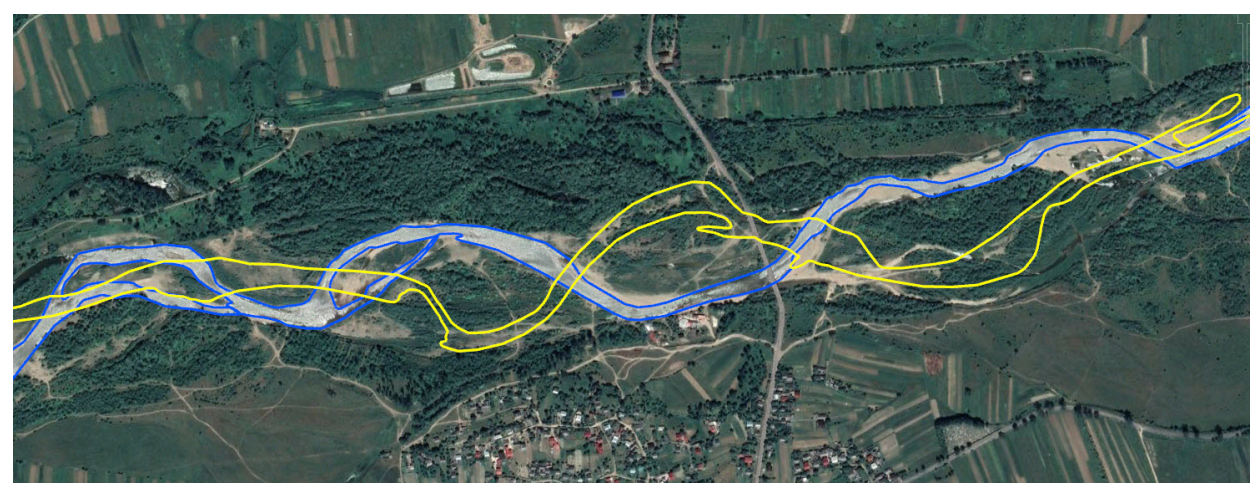

Figure 5. Dynamic of Limnitsa riverbed's changing on the basis of space images processing. The riverbed is selected by contour in 2018 year and in 2005 year 
540 tons of solid waste per year were formed, those waste contained more than $90 \%$ hexachlorobenzene which is a resistant organic polluter. This substance is slowly degraded and has the capacity to collect in the food chain. Hexachlorobenzene is a possible carcinogen for the human, confirmed carcinogen for animal and high toxic for water organisms. Formed high toxic wastes in a few years after their accumulation were decided to bury in the special polygon's limits. Metal packaging with toxic substance was wrecked during more 20 years after it was buried in the ground and the territory was leveled. Those non-hermetic kegs with toxic substance during more 20 years after they were buried in the swamp and were in the zone of groundwater influence and corroded with all consequences. Civil society of the city was concerned about possible negative influence on the environment and the human health. Civil society had taken the initiative of constant objective monitoring establishment for the state of this facility. Unfortunately this legitimate claim till nowadays was not enforced. Instead, the decision about substance's exporting was taken. All volume of hexachlorobenzene's extraction (approximately 11 thousand tons) would not be possible because of the method of waste disposal and corrosion process' impact during long timescale. This procedure would be real if this substance in the hermetic packaging would store at the shelves' dry warehouse. Specified quantity of hexachlorobenzene's toxic waste had been increased at least 5-10 times with accounting of soils' large volumes that have been mixed with toxic substance. There are particulars that hexachlorobenzene had been identified in the aquifer in the Kopanky village, which situated
$4.5 \mathrm{~km}$ kilometers from polygon. This fact indicates that toxic chemical compound is washing out from the polygon and transporting by aquifer for a long distance from the burial site.

Other dangerous geodynamic processes. Flooding process in the city has natural causes, because this process is manifested in the rivers' floodplain characterized by flat relief, high levels of groundwater's bedding.

Cluttering of the loch and floodplain by garbage, floodplain's building, restrictions' non-compliance of economic activity in coastal strips are contribute to flooding process. Flooding square by catastrophic high waters of $1 \%$ availability for the Limnitsa River is 901.3 ha, for the Sivka River is 174.4 ha, for the Mlynivka River is 107.9 ha, for Fruniliv River is 13.9 ha, for the Krivets Stream is 3.76 ha (Gajdin et al., 2014).

Surfer landslides (slope and gravital processes) manifest in the form of slope destruction of "Vysochanka" district and other city sites, reflecting the building reconnaissance in the Ivano-Frankivska street. Cracks are observed at the new city hospital's constructions in the "Pidhirky" subdistrict. Landslides are present in the limits of the Central kainite ore field because of this field is characterized by slope steepness' high indexes the sustainability of which was violated due to earth surface subsidence during underground mine workings. Soil's mud streams observed at the north-west slope of "Vysochanka". This district is dangerous for high-altitude buildings' construction based on described above data to geological processes' analysis at the "Vysochanka" district due to mud streams' and landslides' development.

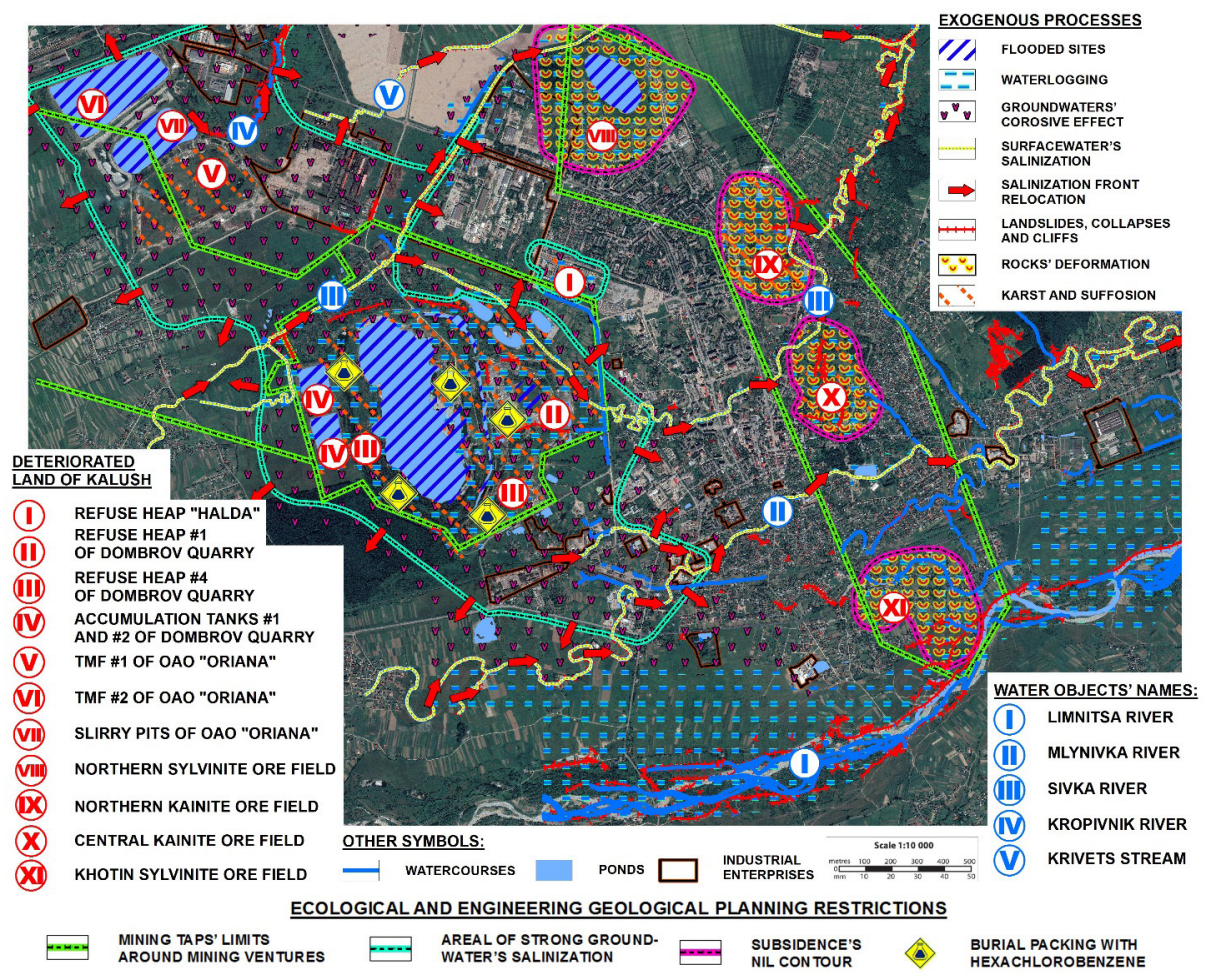

Figure 6. Geoecological situation's map of Kalush city 
The quarry is situated in the district of Kalush brick clay deposit which has activated landslide process. Mine workings have resulted in denudation of Dashava suite's clays and loams and steepness angle of slope's increasing. Landslide activization is connected with the intense rainfalls' period. Clay consistency is changing due to precipitation action and they take on plastic consistency, resulting in rocks' slumping from the slope. At the present time landslide body has a width of $400 \mathrm{~m}$ and length of $250 \mathrm{~m}$. Landslide shelf has a height of 4-8 $\mathrm{m}$. Landslide process is in the active phase, as evidenced by the tensile cracks' presence in the virgin slope.

Geoecological situation's map of Kalush city (fragment on Figure 6) was created on the basis of analysis of specialized enterprises' reports, field researches and ERS materials' interpretation. Mining taps' limits around mining ventures, subsidence's nil contours, areal of strong groundwater's salinization, exogenic processes' manifestations were allocated on mentioned map (Trofimov \& Krasilova, 2008).

\section{Conclusions}

Kalush city of Ivano-Frankivsk region is one of the extraordinary environmental situation zone of Ukraine. The environmental balance in the rock's fatter of the KalushHolyn potassium salt's deposit was violated as a result of chemical enterprises' illiterate economic activity. Such technogenic objects were allocated on the Kalush area among violated territories that destructive impact on geological environmental status: TMF No 1 and No 2, sludge tank of OAO "Oriana" potash plant, Kalush mine, which included Dombrowski quarry's refuse heaps and bowl with mineralized liquid phase, North sylvinite ore field, North kainite ore field, Central kainite ore field and Khotin sylvinite ore field, polygon of hexachlorobenzene's toxic waste, abandoned quarry of clay raw materials. Numerous Earth's surface failures above mine fields' area, destruction of buildings and communications, salinization of aquifers in the city resulted from adoptions of the wrong decisions concerning mining, location and operation TMFs, tips, accumulation tanks and methods for disposing mine voids. Main reasons of present ecological problems in Kalush city are quarry's construction by open-cut method, destruction of circular drainage system, location of refuse heaps of Dombrowski quarry on the earth surface, absence of technically reasoned recultivation of violated lands, nonsustainable exploitation of resources without compliance with environmental requirement.

As a result of an analysis of violated lands' problems the complex map of Kalush city's geoecological situation had been designed that could help to allocate sites with different level of suitability for construction and also this map could act as the basis for engineering protection measures development. We think it is necessary to offer next engineering protection measures for violated lands of Kalush city:
1) Construction of anti-filter curtain around Dombrowski quarry's refuse heaps No 1 and No 4, accumulation tanks No 1 and No 2 to the border of Sivka floodplain for the stopping of salinize groundwater discharge into rivers of Kalush city. Gradual brines' recycling and exemption of valuable mineral commodities from heaps are required. Once the desalination of brines had been achieved and refuse heaps will not contain any conditional deposits, specified territories should be recultivated by forest park creation and recreational zone without capital construction. The long-term engineering geological monitoring for specified territory for the activization's prevention of dangerous exogenic geological processes is also required;

2) For all ore fields the brines' pumping through wells with their subsequent processing with simultaneous injection into the wells of pulp with silicates is required. Once the suggestions concerning suitability of those territories for the construction or other kinds of economic activities had been formed the long-term engineering geological monitoring for specified territory is required.

3) Polygon of hexachlorobenzene's toxic waste requires for special transportation and utilization beyond the city borders as a high toxic substance.

4) Refuse heap "Halda", abandoned quarry of clay raw materials, TMF No 1 and 2 require recycling and exemption of valuable mineral commodities for chemical and construction industry.

5) Gradual brines' recycling and exemption of valuable mineral commodities are required from sludge tank of OAO "Oriana" potash plant. Sludge may to use for building materials', paints', fillers', mineral fertilizers' manufacturing (Rudko \& Petryshyn, 2015).

All measures mentioned above have to decide problems of violated lands and improve an ecological status of city's environment.

\section{Acknowledgements}

Authors of this article extend deep thanks to officers of State Enterprise Scientific and Research Institute of Halurgy in person of Chief Expert Yuriy Sadoviy and Director Ivan Kostiv and also to specialists of Kalush City Board Executive Committee for proving theoretical and applied materials and engineering cooperation.

\section{Author contributions}

Pavlo Zhyrnov conceived the study and was responsible for the design and development of the data analysis. Olha Tomchenko was responsible for remote sensing data collection and analysis. Iryna Pidlisetska and Olena Mykolaenko were responsible for data interpretation. 


\section{Disclosure statement}

Authors have no competing financial, professional, or personal interests from other parties.

\section{References}

Bagriy, S. (2009). Possibility's assessment of Sivka river's breakthrough in the Dombrovsky quarry of Kalush-Holyn potassium salt deposit. Scientific Bulletin of Ivano-Frankivsk National Technical University of Oil and Gas, 4(22), 44-52. http://elar.nung.edu.ua/handle/123456789/2034

Bagriy, S. (2016). Geophysical monitoring of geological environment in potassium salt deposits' limits on the example of Kalush-Holyn deposit [PhD thesis]. Ivano-Frankivsk National Technical University of Oil and Gas, Ivano-Frankivsk, Ukraine. http://elar.nung.edu.ua/handle/123456789/31

Bagriy, S., \& Kuzmenko, E. (2011). About appropriateness of karst researches by electric methods at potassium and rock salt deposits. Geodynamics, 2(11), 134-137.

http://ena.lp.edu.ua:8080/handle/ntb/11896

Chepurnyi, I., Bagriy, S., Kuzmenko, E., \& Chepurna, T. (2020). Time series analysis of karst breakdown development on the potassium salt deposit areas within Precarpathian region. Journal of Geology, Geography and Geoecology, 29(2), 258- https://doi.org/10.15421/112024

Deshchytsya, S., Pidvirny, O., Romanyuk, O., Sadovyi, Y., Kolyadenko, V., Savkiv, L., \& Myshchyshyn, Y. (2016). Evaluation of the state of ecologically problematic mining and industrial objects in Kalush region by electromagnetic methods and their monitoring. Science and Innovation, 12(5), 41-51. https://doi.org/10.15407/scine12.05.041

Gajdin, A., Maciaszek, J., \& Szewczyk, J. (2014). The influence of the inundation of the potassium open pit in Kalush on the environment predictions and facts. Geomatics and Environmental Engineering, 8(4), 15-24.

https://doi.org/10.7494/geom.2014.8.4.15

Holovchak, V. (2010). Mining and industrial geocomplexes' state of potassium salts' Kalush-Holynsky deposit and measures for their ecological optimization. Ecological Safety and Balanced Use of Resources, 2(2), 4-12. https://ebzr.nung.edu.ua/index. php/ebzr/article/view/327/333

Kolodova, V., Shitik, O., Sukhina, L., Zhyrnov, P., Boldyriva, O., Petyur, A., Lopatyuk, M., Malyuk, H., Svyatnenko, L., \& Yuzko, O. (2020). Master plan of Kalush city. Research and Design Institute of Urban Planning, SE, Kyiv. https://kalushcity.if.ua/ files/dok/_\%D0\%9A\%D0\%90\%D0\%9B\%D0\%A3\%D0\%A8\% C2\%A0(2)_1.pdf

Krizhanivsky, E., Kuzmenko, M., Paliychuk, B., \& Baranenko, T. (2008). Technogenic situation in the area of Kalush industrial hub. Scientific Bulletin of Ivano-Frankivsk National Technical University of Oil and Gas, 2(18), 3-9. http://elar.nung.edu.ua/ handle/123456789/1750
Malyk, Y., Demkiv, O., \& Petrushka, I. (2013). Monitoring of environmental state of places of mineral concentration waste storage. Bulletin of Lviv State University of Life Safety, 7, 194197. https://ldubgd.edu.ua/sites/default/files/files/malyk_7. pdf

Mykolaenko, O., Zhyrnov, P., Sadoviy, Y., Tomchenko, O., \& Pidlisetska, I. (2019). Assessment engineering geological zoning of Kalush city using ERS data for urban development. In 18th International Conference on Geoinformatics: Theoretical and Applied Aspects, (pp. 1-5).

https://doi.org/10.3997/2214-4609.201902029

Office of the President of Ukraine. (2010). Presidential Decree No145/2010 of 10 February 2010 on declaring the territories of the city of Kalush and the villages of Kropyvnyk and Sivka-Kaluska of the Kalush district of Ivano-Frankivsk region a zone of ecological emergency. https://zakon.rada.gov.ua/laws/ show/145/2010\#Text

Pakshyn, M., Lyaska, I., Burak, K., Kovtun, V., Dorosh, L., Hrynishak, M., Mykhailyshyn, V., \& Grytsyuk, T. (2019). Estimation of earth's surface moves and deformation of the territory of mine "Khotin" of Kalush-Golinskyy field by method of radar interferometry. Geodesy and Cartography, 45(1), 37-42. https://doi.org/10.3846/gac.2019.6300

Pavliuk, V. (2016). The influence of the technogenic factors in the karst activization of the Precarpathians salt sediments and the karst natural lows. Geology, Geophysics and Environment, 42(2), 175-183. https://doi.org/10.7494/geol.2016.42.2.175

Rudko, G., \& Petryshyn, V. (2015). Problems of ecological situation stabilization in Kalush mining region. Ecological Sciences, 1(7), 163-186. http://www.ecoj.dea.kiev.ua/archives/2015/7/20.pdf

Sadoviy, Y., \& Tsimbalista, G. (2017). Mining and exploration restrictions' identification for the master plan of the Kalush city. SRIH, SE, Kalush.

Shurovsky, O., Anikev, S., Shamotko, V., Deshitsya, S., Nikolaenko, O., \& Poplyuiko, A. (2012). Geophysical monitoring of dangerous geological processes in the Kalush city agglomeration. Mineral resources of Ukraine, 2, 31-38. https://www.geo. gov.ua/wp-content/uploads/2018/06/2_2012_Mru.pdf

Trofimov, V., \& Krasilova, N. (2008). Engineering geological maps. Moscow State University Publishing House.

Yosipenko, T. (2012). Complex geophysical investigations for the purpose of karst processes' projection and potable underground waters' pollution of the Kalush city. Ukrgeophysics, SE, Kyiv.

Zhyrnov, P., Sadoviy, Y., \& Tomchenko, O. (2019). Methodology for the territories' engineering construction assessment with difficult geological conditions. In IX International Youth Science Forum "Litteris et Artibus" (pp. 1-7). https://openreviewhub.org/lea/paper-2019/methodology-territories-engineering-construction-assessment-difficult-geological 